\title{
Prevalence of antibody to human T cell leukaemia/ lymphoma virus in women attending antenatal clinic in southeast London: retrospective study
}

\author{
Matthew Donati, Habib Seyedzadeh, Teresa Leung, Maggie Blott, Mark Zuckerman
}

Public Health Laboratory and Medical

Microbiology, Department of Virology, Guy's, King's and

St Thomas's School of Medicine, King' College Hospital (Dulwich), London SE22 8QF

Matthew Donat specialist registrar in virology

Habib Seyedzadeh grade 1 medical laboratory scientific officer

Teresa Leung grade 2 medical laboratory scientific officer

Mark Zuckerman consultant virologist Department of Obstetrics and Gynaecology, King's Healthcare Trust, London SE5 9RS

Maggie Blott consultant obstetrician and gynaecologist Correspondence to: M Zuckerman mark.zuckerman@ kcl.ac.uk

BMJ 2000;320:92-3
Infection with human $\mathrm{T}$ cell leukaemia/lymphoma virus (HTLV) type I occurs mainly in Japan, central and west Africa, and the Caribbean basin. Infection confers a lifetime risk of $2-4 \%$ for adult $\mathrm{T}$ cell leukaemia or lymphoma and $0.2-5 \%$ for tropical spastic paraparesis. However, the incubation period for these conditions after naturally acquired infection may be several decades. ${ }^{1}$ The virus is transmitted via infected lymphocytes, and in areas of high prevalence breast feeding is an important route of transmission, particularly if continued for over six months. ${ }^{2}$

We determined the prevalence of HTLV antibody in women who had attended antenatal clinics at King's Healthcare NHS Trust, southeast London, to assess whether antenatal screening should be considered locally.

\section{Subjects, methods, and results}

With the approval of the local ethics committee, we tested sera that had been collected routinely at antenatal clinics between January 1994 and December 1996 for HTLV antibody. The samples were anonymised for patient's name and hospital number, but data on ethnicity, age, and partner's ethnicity were retained.

We initially pooled sera from five separate samples in a single assay well and used an enzyme linked immunoassay for HTLV antibody (Murex Biotech, Dartford, product code GE80/81). When the assay was reactive for a pool, we tested each sample using the same assay. Reactivity was then confirmed with a passive particle agglutination test (Serodia HTLV-I, Fujirebio, Tokyo, Japan), and we used an immunoblot assay to discriminate between HTLV types (Inno-Lia, HTLV I/II antibody assay, Innogenetics NV, Belgium).
We tested 8656 samples altogether and identified 110 reactive pools. These pools yielded 34 samples positive for HTLV antibody $(0.39 \%, 95 \%$ confidence interval $0.26 \%$ to $0.52 \%)-32$ with HTLV type I $(0.37 \%)$, one with HTLV type II $(0.01 \%)$, and one that was untypable. One sample gave an indeterminate antibody result. The table shows the overall results.

\section{Comment}

We found the seroprevalence of antibody to human $\mathrm{T}$ cell leukaemia/lymphoma virus was $0.39 \%$ among pregnant women in southeast London over a 36 month period. This result probably reflects the ethnic composition of the local residents of Lambeth, Lewisham, and Southwark, about 18\% of whom are black (1991 census data).

The policy of not screening for HTLV antibody in pregnant women and in blood and organ donors is partly based on its perceived low prevalence and the low lifetime risk of associated disease. Although the cost of antenatal screening could be limited by selecting those women thought to be at high risk, this would require knowledge of the ethnicity details of current and previous sexual partners in order to be comprehensive. Such information might be difficult to obtain. In our study HTLV infection was not limited to women who described themselves as black African or black Caribbean, a finding that was also reported in the West Midlands. ${ }^{3}$ Three white women were infected, of whom two were born in Britain and one in Jamaica, and all three had black Caribbean partners. We also found HTLV antibody in 10 women born in Britain who described themselves as either black African of black Caribbean.

Table 1 Results of testing sera from women attending antenatal clinics for antibody to human T cell leukaemia/lymphoma virus (HTLV)

\begin{tabular}{|c|c|c|c|c|c|c|c|c|}
\hline \multirow[b]{2}{*}{ Ethnic group } & \multicolumn{2}{|c|}{1994} & \multicolumn{2}{|r|}{1995} & \multicolumn{2}{|c|}{1996} & \multicolumn{2}{|r|}{ Total } \\
\hline & $\begin{array}{c}\text { No of } \\
\text { patients }\end{array}$ & $\begin{array}{c}\text { No }(\%) \text { of } \\
\text { positive } \\
\text { results }\end{array}$ & $\begin{array}{c}\text { No of } \\
\text { patients }\end{array}$ & $\begin{array}{c}\text { No (\%) of } \\
\text { positive results }\end{array}$ & $\begin{array}{c}\text { No of } \\
\text { patients }\end{array}$ & $\begin{array}{c}\text { No (\%) of } \\
\text { positive } \\
\text { results }\end{array}$ & $\begin{array}{l}\text { No }(\%) \text { of } \\
\text { patients }\end{array}$ & $\begin{array}{c}\text { No }(\%, 95 \% \mathrm{CI}) \text { of } \\
\text { positive results }\end{array}$ \\
\hline Black African & 512 & $7^{\star}(1.37)$ & 567 & $2(0.35)$ & 624 & $3(0.48)$ & $1703(19.67)$ & $12(0.70,0.3$ to 1.1$)$ \\
\hline Black Caribbean & 402 & $6(1.49)$ & 403 & $10(2.48)$ & 457 & $3(0.66)$ & $1262(14.58)$ & $19(1.51,0.8$ to 2.2$)$ \\
\hline Black other† & & & 18 & 0 & 36 & 0 & $54(0.62)$ & 0 \\
\hline White & 1043 & $3(0.29)$ & 1045 & 0 & 1155 & 0 & $3243(37.47)$ & $3(0.09,0.0$ to 0.2$)$ \\
\hline Mixed race & 87 & 0 & 87 & 0 & 103 & 0 & $277(3.20)$ & 0 \\
\hline $\begin{array}{l}\text { Indian, Pakistani, } \\
\text { Bangladeshi }\end{array}$ & 79 & 0 & 71 & 0 & 91 & 0 & $241(2.78)$ & 0 \\
\hline Asian, oriental & 43 & 0 & 51 & 0 & 70 & 0 & $164(1.89)$ & 0 \\
\hline Others & 88 & 0 & 137 & 0 & 166 & 0 & $391(4.52)$ & 0 \\
\hline Not stated & 745 & 0 & 330 & 0 & 246 & 0 & $1321(15.26)$ & 0 \\
\hline Total & 2999 & $16(0.53)$ & 2709 & $12(0.44)$ & 2948 & $6(0.20)$ & 8656 & $34(0.39,0.26$ to 0.52$)$ \\
\hline
\end{tabular}

${ }^{*}$ Includes one infection with HTLV type II and one untypable infection. All other positive results were for HTLV type I.

†Not included as an option in ethnic group until 1995. 
The prevalence of HTLV antibody was similar to that reported for HIV in the same population at the same time. ${ }^{4}$ With appropriate counselling, screening for HTLV should be accepted in the same light as testing for HIV, which has recently been recommended as part of the routine antenatal screening programme. ${ }^{5}$ However, unlike HIV infection, infection with HTLV is less likely to become clinically apparent, and the factors conferring a high risk of developing associated disease have not been defined. In the meantime, antenatal screening could help limit vertical transmission.

We thank Dr Jennifer Tosswill, Virus Reference Laboratory, Central Public Health Laboratory, London, for further analysis of three samples sent for confirmation of antibody status; Natalie Ives for the statistical analysis of the data; and the staff in the department of virology at Dulwich Public Health Laboratory for their help with this study.

Contributors: MD helped with writing the paper, preparing samples for testing, and analysing the results. HS performed much of the sample testing and helped with analysing the results. TL helped with constructing the database of partici- pants' details and analysing the results. MB helped with designing the study and drafting the article. MZ designed the study, helped with analysing data and revising the article, and is the guarantor for the study. Pam Dobson, computer liaison midwife at King's Healthcare Trust, provided the demographic data for the antenatal clinic attendees. All authors reviewed the manuscript.

Funding: Internal sources only.

Competing interests: None declared.

1 Ferreira OC Jr, Planelles JD, Rosenblatt JD. Human T-cell leukemia viruses: epidemiology, biology, and pathogenesis. Blood Rev 1997;11:91104.

2 Takezaki T, Tajima K, Ito M, Ito S-I, Kinoshita K-I, Tachibana K, et al. Short-term breast-feeding may reduce the risk of vertical transmission of HTLV-I. Leukemia 1997;11(suppl 3):60-2.

3 Nightingale S, Orton D, Ratcliffe D, Skidmore S, Tosswill J, Desselberger $\mathrm{U}$. Antenatal survey for the seroprevalence of HTLV-1 infections in the West Midlands, England. Epidemiol Infect 1993;110:370-89.

4 Department of Health. Prevalence of HIV in England and Wales in 1997. Annual report of the unlinked anonymous HIV prevalence monitoring programme. London: DoH, 1998.

5 Intercollegiate Working Party for Enhanced Voluntary Confidential HIV Testing in Pregnancy. Reducing mother to child transmission of HIV infection in the United Kingdom. London: Royal College of Paediatrics, 1998.

(Accepted 7 October 1999)

\section{Drug points}

\section{Acute renal failure induced by topical ketoprofen}

T Krummel,Y Dimitrov, B Moulin, T Hannedouche, Department of Nephrology, Hôpitaux Universitaires, Strasbourg, France

Acute renal failure is a known complication with oral nonsteroidal anti-inflammatory drugs. ${ }^{12}$ In contrast, topical application of such drugs is usually considered safe because of marginal percutaneous absorption $(5-8 \%){ }^{3}$ We report a case of acute renal failure after treatment with topical ketoprofen.

A 62 year old Turkish woman with chronic renal failure from polycystic kidney disease had had stable renal function for several months, with a creatinine concentration of $360 \mu \mathrm{mol} / \mathrm{l}$, and stable treatment, (rilmenidine, furosemide, atenolol, amlodipine, enalapril, aspirin, sodium bicarbonate, simvastatin, dietary salt restriction). She was admitted for inflammatory arthritis of one ankle and was treated with colchicine ( $1 \mathrm{mg}$ /day), without digestive intolerance, and topical ketoprofen twice daily for five days. Her serum creatinine and urea concentrations rose from $390 \mu \mathrm{mol} / \mathrm{l}$ and $25 \mathrm{mmol} / 1$ to $673 \mu \mathrm{mol} / \mathrm{l}$ and 38 $\mathrm{mmol} / \mathrm{l}$ respectively by the fifth day of treatment. Diuresis was unchanged, but urinary sodium and fractional sodium excretion fell, suggesting functional acute renal failure. No urinary or blood eosinophilia were found. Treatment with ketoprofen, enalapril, and furosemide were immediately stopped, and her renal function returned to its initial level after eight days. Her blood concentration of free unbound ketoprofen was $4.17 \mathrm{mg} / 1$ six days after stopping ketoprofen (normal range for oral ketoprofen 5-10 mg/l).

Systemic non-steroidal anti-inflammatory drugs can induce renal failure in two ways. Acute interstitial nephritis, with or without nephrotic syndrome, is relatively rare and is presumably due to a dose independent allergic mechanism. ${ }^{1}$ Non-selective inhibition of cyclo-oxygenases 1 and 2, causes a functional reversible acute renal failure. Cyclo-oxygenase 2 is selectively induced by proinflammatory cytokines at inflammation sites, but cyclo-oxygenase 1 is constitutionally expressed in many tissues, including the kidney, especially in situations in which renal perfusion is compromised. In these situations oral non-steroidal anti-inflammatory drugs are contraindicated.

In this case, chronic renal failure, treatment with angiotensin converting enzyme inhibitors and diuretics, and age were all high risk factors for acute renal failure with non-steroidal anti-inflammatory drugs. ${ }^{12}$ The renal was probably due to ketoprofen treatment, given the rise in serum creatinine concentration and high blood concentration of ketoprofen detected. This case illustrates that transdermal absorption of ketoprofen can cause high blood concentrations. Renal failure is a predisposing condition as it can reduce clearance of ketoprofen. ${ }^{4}$ Acute renal failure after treatment with topical non-steroidal anti-inflammatory drugs has been reported previously: two cases after application of piroxicam and ibuprofen (probably allergic reactions), and another after treatment with $3 \%$ benzydamine. ${ }^{25}$ None reported blood concentrations of the drugs.

This case shows that topical treatment with ketoprofen can result in blood concentrations and systemic effects comparable to those from oral treatment. Topical non-steroidal anti-inflammatory drugs should be used with the same precautions as other forms of the drugs in high risk patients, especially those with reduced drug metabolism as in renal failure.

1 Sandler D, Burr R, Weinberg C. Nonsteroidal anti-inflammatory drug and the risk for chronic renal disease. Ann Intern Med 1991;115(3):16572

2 O'Callaghan CA, Andrews PA, Ogg C. Renal disease and use of topical non-steroidal anti-inflammatory drugs. BMJ 1994;308:110-1.

3 Shah A, Wei G, Lanman R, Bhargava V, Weir S. Percutaneous absorption of ketoprofen from different anatomical sites in man. Pharm Res 1996;13(1):168-72.

4 Skeith KJ, Dasgupta M, Lange R, Jamali F. The influence of renal function on the pharmacokinetics of unchanged and acyl-glucuroconjugated ketoprofen enantiomers after 50 and $100 \mathrm{mg}$ racemic ketoprofen. $\mathrm{Br} J$ Clin Pharmacol 1996;42:163-9.

5 Fernando A, Thomas S, Temple R, Lee H. Renal failure after topical use of NSAIDs. BMJ 1994;308:533. 